\title{
Ursolic acid and rosiglitazone combination alleviates metabolic syndrome in high fat diet fed C57BL/6J mice
}

\author{
Arjunan Sundaresan, Ranganathan Harini and Kodukkur Viswanathan Pugalendi
}

Faculty of Science, Department of Biochemistry and Biotechnology, Annamalai University, Annamalainagar 608 002 , Tamilnadu, India

\begin{abstract}
The aim of this study was to examine the combined effect of ursolic acid (UA) and rosiglitazone (RSG) on metabolic syndrome in C57BL/6J mice. Upon feeding high fat diet (HFD) C57BL/6J mice developed obesity, insulin resistance, dyslipidemia and hypertension. The male mice were randomly divided into six groups, and fed normal diet, normal diet plus UA and RSG, HFD alone, HFD plus UA, HFD plus RSG, and HFD plus UA and RSG, respectively. HFD fed mice showed increase in body weight, elevated plasma glucose and insulin. Activities of gluconeogenic enzymes such as glucose 6-phosphatase, fructose 1,6-bisphosphatase increased while the activity of glycolytic enzyme, glucokinase, decreased in the liver along with glycogen content. Total cholesterol, triglyceride, low-density lipoprotein cholesterol and very low-density lipoprotein cholesterol and free fatty acid levels significantly increased in the plasma, whereas high-density lipoprotein cholesterol significantly decreased in high fat diet fed mice. In addition, both systolic and diastolic blood pressure was increased significantly. Combined treatment with UA and RSG improved the above parameters towards normality and pronounced more responses than UA or RSG lone treatment. The inclusion of UA in treatment with RSG may reduce the body weight gain, one of adverse side effect associated with the RSG-therapy.
\end{abstract}

Key words: Metabolic Syndrome — High fat diet - Ursolic acid - Rosiglitazone - C57BL/6J mice

\begin{abstract}
Abbreviations: Hb, haemoglobin; HbAlc, glycosylated haemoglobin; HDL-C, high-density lipoprotein cholesterol; HFD, high fat diet; LDL-C, low-density lipoprotein cholesterol; PPAR- $\gamma$, peroxisome proliferator-activated receptor- $\gamma$; RSG, rosiglitazone; TC, total cholesterol; TG, triglyceride; TZD, thiazolidinedione; UA, ursolic acid; VLDL-C, very low-density lipoprotein cholesterol.
\end{abstract}

\section{Introduction}

Insulin resistance concomitant with obesity, type-2 diabetes mellitus, hypertension, and other features of the metabolic syndrome is a major risk factor for cardiovascular diseases, the leading cause of mortality and morbidity (DeFronzo 2004). Insulin resistance plays a central role in pathogenesis of metabolic syndrome as well as overt diabetes (Yip et al. 1998). Lipid metabolic disorders underlie the etiological basis of the metabolic syndrome and are the major con-

Correspondence to: Kodukkur Viswanathan Pugalendi, Department of Biochemistry and Biotechnology, Faculty of Science, Annamalai University, Annamalainagar-608 002, Tamilnadu, India E-mail: pugale@sify.com stituent of metabolic syndrome (Kolovou et al. 2005). There is a need of most composite agent for treating metabolic syndrome as is characterized by many etiologically linked or even exclusively or mutually independent manifestations like dyslipidemia, hyperglycemia, hyperinsulinemia, insulin resistance and hypertension.

Treatment of metabolic syndrome mainly involves the use of thiazolidinediones (TZDs) like rosiglitazone (RSG) improving insulin resistance and dyslipidemia (Lim et al. 2009). However, due to unwanted side effects, the efficacies of these compounds are debatable and there is a demand for new compounds for the treatment of metabolic syndrome. The combination of TZDs with other hypoglycaemics such as sulphonylureas, meglitinide derivatives or biguanides augments their effect (Scheen 2005). 
Ursolic acid (UA; $3 \beta$-hydroxy-urs-12-en-28-oic acid), a natural pentacyclic triterpenoid carboxyl acid, is the major component of some traditional medicinal herbs and is well known to possess a wide range of biological functions, including anticancer (Sohn et al. 1995), antioxidative (Balanehru and Nagarajan 1991), hepatoprotective (Liu 1995) and hypolipidemic, antiatherosclerotic (Somova et al. 2003). From our laboratory, Senthil et al. (2007) reported the protective effect of UA against isoproterenol-induced myocardial ischemic injury in rats and Saravanan and Pugalendi (2006) reported that UA coadministration with ethanol would protect the heart probably by suppressing cellular oxidative stress from ethanol-induced oxidative damage. Zhang et al. (2006) reported that ursolic acid inhibits protein tyrosine phosphatase $1 \mathrm{~B}$, which enhances insulin receptor phosphorylation and stimulates glucose uptake. RSG, a member of the TZD class of antidiabetic agents, is a selective synthetic ligand of the nuclear transcription factor peroxisome proliferator-activated receptor- $\gamma$ (PPAR- $\gamma$ ), acts primarily as insulin sensitizer (Diamant and Hein 2003). Expression of these receptors is most abundant in adipose tissue where they play a central role in adipogenesis and lipid metabolism (Vidal-Puig et al. 1977). However, weight gain and edema can occur with such treatment (Masoudi et al. 2003). Because people with diabetes are at increased risk for cardiovascular disease and may have preexisting heart disease, weight gain and edema can be a concern.

C57BL/6J models have been used for investigation of human obesity and metabolic syndrome (Feldstein et al. 2003). When raised on a high fat diet (HFD), animals develop central adiposity, insulin resistance, hyperinsulinemia, hyperglycemia, dyslipidemia and hypertension (Surwit et al. 1998) in the C57BL/6J mice closely parallel the progression of common forms of the human diseases. We hypothesized that a combination of UA with RSG would take away the side effects of RSG i.e. weight gain but retain their beneficial effects on glucose and lipid metabolism. We therefore evaluated the effects of UA and RSG combination on glucose and lipid metabolism in HFD-fed insulin resistance C57BL/6J mice.

\section{Materials and Methods}

\section{Animals}

Male C57BL/6J mice were purchased from National Institute of Nutrition (Hyderabad) at 5 weeks of age. The mice were housed in a room maintained at a controlled temperature $\left(23 \pm 1^{\circ} \mathrm{C}\right)$ and 12 -h light/12-h dark cycle at Central Animal House, Department of Experimental Medicine, Rajah Muthiah Medical College and Hospital,
Annamalai University. Animals were given free access to water and food. The study protocols were approved by the Institutional Animal Ethics Committee of Rajah Muthiah Medical College and Hospital (Reg No. 160/1999/CPCSEA, Proposal number: 631), Annamalai University, Annamalainagar.

\section{Chemicals}

UA was obtained from Sigma-Aldrich (U6753; St. Louis, Missouri, USA). RSG (Windia) was purchased from Glaxo SmithKline, Mumbai, India. All other chemicals used in this study were of analytical grade obtained from E. Merck or HIMEDIA, Mumbai, India.

\section{Diet}

The standard diet consisted of a balanced diet containing protein $21.1 \%$, fat $5.1 \%$, carbohydrate $60.0 \%$, fiber $3.9 \%$, minerals $7.9 \%$ and vitamins $2.0 \%$.

$40 \%$ high fat diet (HFD) was prepared by mixing beef tallow (34.1\%) with standard pellet diet every day. All measures were taken to ensure uniform mixing of the additives of the diet before kneading using a little water.

\section{Experimental design}

Test animals were fed initially, before the study, with standard diets. Then these were assigned to one of six groups with 10 mice in each group:

Group 1 received standard pellet diet for 15 weeks;

Group 2 received UA ( $5 \mathrm{mg} / \mathrm{kg}$ b.w.) and RSG (4 mg/kg b.w.) for last five weeks;

Group 3 received HFD for 15 weeks;

Group 4 received HFD for first 10 weeks then oral administration of UA ( $5 \mathrm{mg} / \mathrm{kg}$ b.w.) along with HFD for next 5 weeks;

Group 5 received HFD for first 10 weeks then oral administration of RSG (4 mg/kg b.w.) along with HFD for next 5 weeks;

Group 6 received HFD for first 10 weeks then oral administration of UA ( $5 \mathrm{mg} / \mathrm{kg}$ b.w.) and RSG (4 mg/ $\mathrm{kg}$ b.w.) along with HFD for next 5 weeks.

UA and RSG were administered as suspensions directly into the stomach using a gastric tube in the morning for last fast 5 weeks, the former, by mixing with vehicle $0.5 \%$ dimethyl sulfoxide, and the latter, in drinking water.

Body weight and food intake of mice were measured weekly once. At the end of the experimental period, mice were sacrificed by cervical dislocation. Blood was collected by cutting the jugular vein into heparinised glass tubes. Plasma was obtained from blood samples after centrifugation $(1500 \times g$ for $10 \mathrm{~min})$ and stored at $4^{\circ} \mathrm{C}$ until analysis. After 
collecting the blood, the liver and the epididymal fat were removed, rinsed with physiological saline and used for the various biochemical parameters.

\section{Liver homogenate preparation}

Liver tissue was sliced into pieces and homogenized in appropriate buffer ( $\mathrm{pH}$ 7.0) in cold condition to give 10\% homogenate $(\mathrm{w} / \mathrm{v})$. The homogenate was centrifuged at 1000 $\mathrm{rpm}$ for $10 \mathrm{~min}$ at $0^{\circ} \mathrm{C}$ in a cold centrifuge. The supernatant was separated and used to measure carbohydrate metabolic enzyme activities.

\section{Estimation of plasma glucose, insulin, blood $\mathrm{Hb}$ and $\mathrm{HbAlc}$}

Plasma glucose level was measured by enzymatic method using commercial kit (Agappe Pharmaceutical, Kerala, India) with a semi-autoanalyser. The plasma insulin (Medgenix-INS-ELISA, Biosource, Europe S.A., Belgium) level was determined using a radioimmunoassay kit. The assay was based on the oligoclonal system in which several monoclonal antibodies directed against distinct epitopes of insulin (Burgi et al. 1998). Haemoglobin (Hb) was estimated by the method of Drabkin and Austin (1932). Glycosylated haemoglobin (HbA1c) was estimated by the method of Sudhakar and Pattabiraman (1981).

\section{Estimation of lipid profile}

Total cholesterol (TC), triglyceride (TG) and high-density lipoprotein cholesterol (HDL-C) levels in plasma were determined using commercially available kits according to the instructions of the manufacturer (Agappe Pharmaceutical, Kerala, India) with a semi-autoanalyser. Low-density lipoprotein cholesterol (LDL-C) and very low-density lipoprotein cholesterol (VLDL-C) were calculated from TG, TC and HDL-C concentrations following Friedewald formula (Friedewald et al. 1972): VLDL cholesterol $=\mathrm{TG} / 5$ : LDL-C $=$ TC $-[$ HDL-C+VLDL-C]. Free fatty acids (FFA) in the plasma were estimated by the method of Falholt et al. (1973).

\section{Estimation of hepatic glucose regulating enzyme activities and glycogen level}

Assay of hexokinase D (glucokinase). Hexokinase D was assayed by the method of Brandstrup et al. (1957). The reaction mixture in a total volume of $5.5 \mathrm{ml}$ contained the following: $1.0 \mathrm{ml}$ of $0.005 \mathrm{M}$ glucose solution, $0.5 \mathrm{ml}$ of $1 \mathrm{M}$ ATP, $0.5 \mathrm{ml}$ of $0.05 \mathrm{M} \mathrm{MgCl}_{2}, 0.5 \mathrm{ml}$ of $0.0125 \mathrm{M}$ dipotassium hydrogen phosphate solution, $0.4 \mathrm{ml}$ of $0.1 \mathrm{M} \mathrm{KCl}$, $0.1 \mathrm{ml}$ of $0.5 \mathrm{M} \mathrm{NaF}$ solution and $2.5 \mathrm{ml}$ of Tris- $\mathrm{HCl}$ buffer (0.01 M; pH 8.0). The mixture was preincubated at $37^{\circ} \mathrm{C}$ for $5 \mathrm{~min}$. The reaction was initiated by the addition of $1.0 \mathrm{ml}$ of liver tissue homogenate. $1.0 \mathrm{ml}$ aliquot of the reaction mixture was taken immediately (zero time) to tubes containing $1.0 \mathrm{ml}$ of $10 \%$ TCA. A second aliquot was removed after $30 \mathrm{~min}$ of incubation at $37^{\circ} \mathrm{C}$ and added to tubes containing $\mathrm{ml}$ of $10 \% \mathrm{TCA}$. The precipitated protein was removed by centrifugation and the residual glucose in the supernatant was estimated by the o-toluidine method of Sasaki et al. 1972. The green colour developed was read in a colorimeter at $620 \mathrm{~nm}$. A reagent blank was run with each test. The difference between the two values gave the amount of glucose phosphorylated.

Assay of fructose 1,6-bisphosphatase. 1, 6-bisphosphatase was assayed by the method of Gancedo and Gancedo (1971). The assay medium in a final volume of $2.0 \mathrm{ml}$ contained $1.0 \mathrm{ml}$ of Tris- $\mathrm{HCl}$ buffer $(0.1 \mathrm{M}, \mathrm{pH} 7.0), 0.4 \mathrm{ml}$ of substrate as fructose 1,6- bisphosphate $(0.05 \mathrm{M}), 0.1 \mathrm{ml}$ each of magnesium chloride $(0.1 \mathrm{M}), 2 \mathrm{ml}$ potassium chloride $(0.1 \mathrm{M}), 0.1 \mathrm{ml}$ of $0.001 \mathrm{M}$ EDTA and $0.2 \mathrm{ml}$ of enzyme source. The incubation was carried out at $37^{\circ} \mathrm{C}$ for $15 \mathrm{~min}$. The reaction was terminated by the addition of $2 \mathrm{ml}$ of $10 \%$ TCA. The suspension was centrifuged and the phosphorus content of the supernatant was estimated according to the method described by Fiske and Subbarow (1925) To $1 \mathrm{ml}$ of an aliquot of the supernatant, $0.3 \mathrm{ml}$ of distilled water and $0.5 \mathrm{ml}$ of ammonium molybdate $(2.5 \%$ ammonium molybdate in $3 \mathrm{~N}$ sulphuric acid) were added. After $10 \mathrm{~min}, 0.2 \mathrm{ml}$ of 1-amino-2-naphthol-4-sulphonic acid (ANSA) was added. The tubes were shaken well, kept aside for $20 \mathrm{~min}$ and the blue color developed was read at $620 \mathrm{~nm}$.

Assay of glucose 6-phosphatase. Glucose 6-phosphatase was measured by the method of Koide and Oda (1959). The incubation mixture contained $0.3 \mathrm{ml}$ maleic acid buffer $(0.1 \mathrm{M}$, $\mathrm{pH}$ 6.5) $0.5 \mathrm{ml}$ of $0.01 \mathrm{M}$ glucose 6-phosphate and $0.2 \mathrm{ml} \mathrm{liver}$ tissue homogenate. This was incubated at $37^{\circ} \mathrm{C}$ for $1 \mathrm{~h} .1 \mathrm{ml}$ $10 \%$ TCA was added to the tubes to terminate the enzyme activity, then centrifuged and the phosphate content of the supernatant was estimated by Fiske and Subbarow (1925) method. To $1 \mathrm{ml}$ of the aliquot of supernatant, $1 \mathrm{ml}$ of 0.2 $\%$ ammonium molybdate and $0.4 \mathrm{ml}$ ANSA were added. The blue color developed was read after $20 \mathrm{~min}$ at $620 \mathrm{~nm}$. A tube devoid of the enzyme served as control.

Estimation of liver glycogen. Liver glycogen was extracted and estimated by the method of Morales et al. (1975). 50 $\mathrm{mg}$ of fresh liver tissue was digested with $3 \mathrm{ml}$ of $30 \%$ potassium hydroxide solution in a boiling water bath for 15 $\mathrm{min}$. The tubes were cooled and a drop of $1 \mathrm{M}$ ammonium acetate was added to precipitate glycogen and left it in a freezer overnight. Glycogen was collected by centrifug- 
ing at $3000 \mathrm{rpm}$ for $20 \mathrm{~min}$. The precipitate was dissolved by heating and again the glycogen was re-precipitated with $2 \mathrm{ml}$ of $75 \%$ alcohol and a drop of $1 \mathrm{M}$ ammonium acetate and centrifuged. The final precipitate was dissolved in saturated ammonium chloride solution by heating in a boiling water bath for $5 \mathrm{~min}$. Aliquots of glycogen solution were taken and $4 \mathrm{ml}$ of anthrone reagent was added. The tubes were shaken well and heated in a boiling water bath for $20 \mathrm{~min}$. After cooling, the intensity of blue colour was read at $640 \mathrm{~nm}$ against water blank treated in a similar manner.

Blood pressure measurements. Blood pressure was determined by the tail-cuff method (IITC, model 31, Woodland Hills, CA, USA). The animals were placed in a heated chamber at an ambient temperature of $30-34^{\circ} \mathrm{C}$ for 15 min and from each animal, 1-9 blood pressure values were recorded. The lowest three readings averaged to obtain a mean blood pressure. All recordings and data analyses were done using a computerized data acquisition system and software.

Histopathology of adipose tissue. Epididymal fat wedges from representative mice in each group were fixed overnight in $10 \%$ neutral buffered formalin, embedded in paraffin, and cut into thin section $(5 \mu \mathrm{m})$, and mounted on slide glasses. Hematoxylin and eosin (H\&E) staining was performed according to the standard protocol as described by Bancroft and Gamble (2002). Processed tissues were deparaffinized with two changes of xylene for 2 min each, rehydrated with two changes ofabsolute, $95 \%$ and $80 \%$ alcohols for $2 \mathrm{~min}$ each, followed by washing in running tap water for $5 \mathrm{~min}$. Then, the tissues were stained with Harris's haematoxylin for $20 \mathrm{~min}$ and washed inrunning tap water. Differentiation with $1 \%$ acid alcohol was carried out for $10 \mathrm{~s}$, followed by washing and bluing by dipping the tissues in ammonia water for $10 \mathrm{~s}$. After a washing step, thetissues were counterstained with eosin Y for $2 \mathrm{~min}$, dehydrated with increasing graded of alcohols for $2 \mathrm{~min}$ each, cleared with two changes of xylene for 2 min each and finally mounted with dibutyl phthalate xylene (DPX). Micrographs were taken at magnification $\times 20$ (BX41, Olympus, Tokyo).

Adipocyte sizing. The histology sections were viewed at magnification $\times 20$, and images were obtained with digital camera (Olympus, Tokyo). Images were analyzed with National Institutes of Health Image J software. The total number and cross-sectional areas of adipocytes were calculated with the command Measure All. Cross-sectional areas were expressed by the computer as $\mathrm{mm}^{2}$. Results were directly loaded into a spreadsheet program (Excel, Microsoft Inc., Redmond, WA, USA) for analysis. Because each millimeter of the digital image equaled $\sim 50 \mu \mathrm{m}$, the calculated areas were multiplied by a conversion factor of $2500\left(50^{2}\right)$ to determine the crosssectional area of the adipocytes in $\mu \mathrm{m}^{2}$.

\section{Statistical analysis}

Values are given as means \pm S.D. for six readings from ten mice in each group. Data were analyzed by one-way

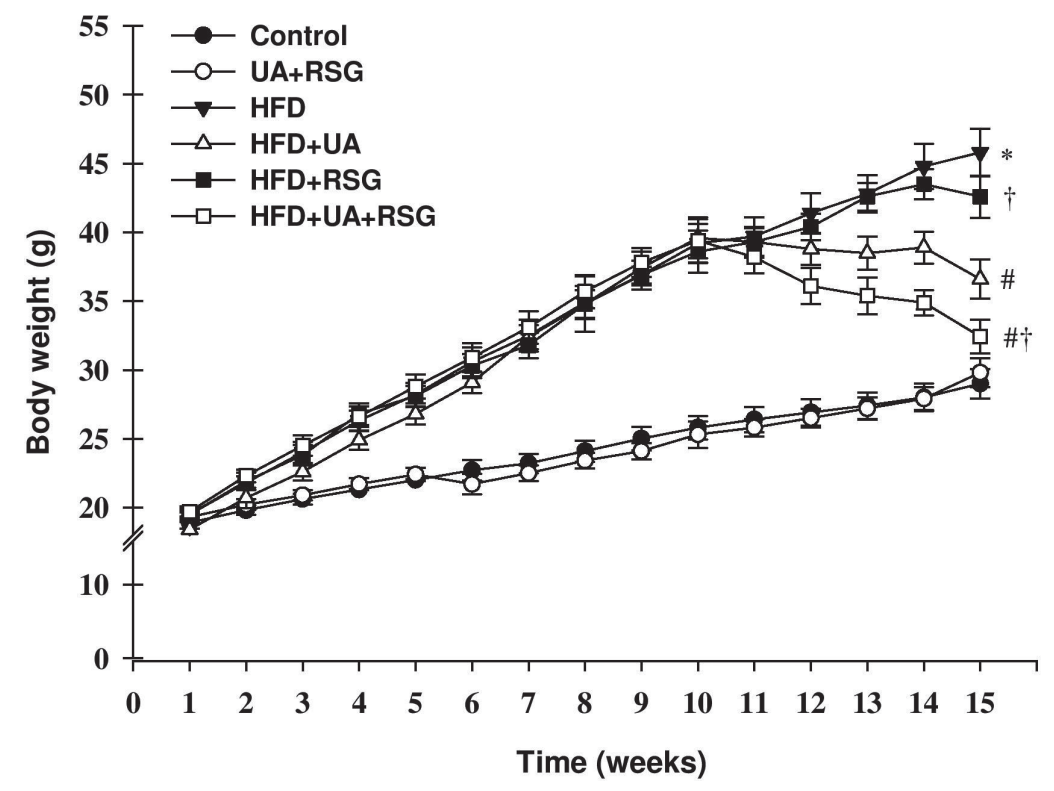

Figure 1. Effect of UA and RSG on body weight in HDF-fed C57BL/6J mice. Values are means \pm S.D. (six readings from ten mice). Duncan's multiple range test (DMRT) was used. ${ }^{*} p \leq 0.05$ compared with control mice; ${ }^{\#, ~} p \leq 0.05$ compared with HFD mice. 
analysis of variance (ANOVA) followed by Duncan's multiple range test (DMRT) using SPSS version 11.5 (SPSS, Chicago, IL). The limit of statistical significance was set at $p \leq 0.05$.

\section{Results}

Body weight, weight gain and epididymal fat content

Figures 1 and 2 show the body weight and epididymal fat content of HFD fed C57BL/6J mice, respectively. The HFD caused a significant increase in body weight in comparison with the control group. The UA and UA/RSG treatment caused a significant reduction in body weight. RSG alone treated group showed an increase in body weight (Figure 1). At $15^{\text {th }}$ week, the epididymal fat content was markedly greater in HFD group. UA alone or combination with RSG significantly suppressed the HFD induced epididymal fat content. RSG treatment increased the epididymal fat content (Figure 2).

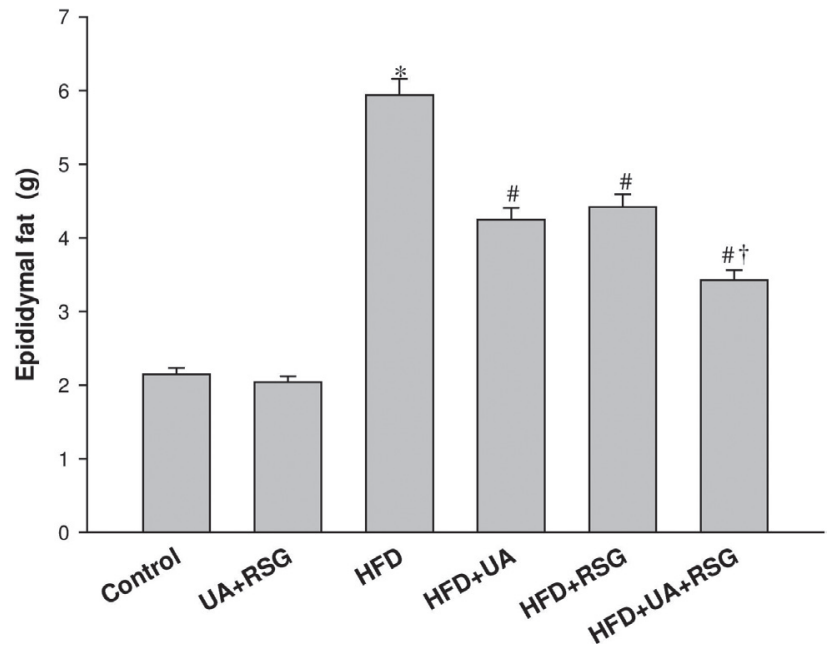

Figure 2. Effect of UA and RSG on epididymal fat pad weight in HDF-fed C57BL/6J mice. Values are means \pm S.D. (six readings from ten mice). Duncan's multiple range test (DMRT). ${ }^{\star} p \leq 0.05$ compared with control mice; ${ }^{\#, \dagger} p \leq 0.05$ compared with HFD mice.

Table 1. Effect of UA and RSG on plasma glucose, insulin, blood Hb and HbA1c levels in HFD-fed C57BL/6J mice

\begin{tabular}{|c|c|c|c|c|c|c|}
\hline & Control & $\mathrm{UA}+\mathrm{RSG}$ & HFD & $\mathrm{HFD+UA}$ & HFD+RSG & $\mathrm{HFD}+\mathrm{UA}+\mathrm{RSG}$ \\
\hline Glucose (mg/dl) & $79.54 \pm 7.85$ & $75.48 \pm 7.43$ & $293.42 \pm 16.54^{*}$ & $149.57 \pm 16.54^{\#}$ & $134.84 \pm 12.79^{\#}$ & $94.75 \pm 8.97^{\dagger}$ \\
\hline Insulin $(\mu \mathrm{U} / \mathrm{ml})$ & $17.34 \pm 1.56$ & $16.71 \pm 1.49$ & $37.24 \pm 2.56^{\star}$ & $28.71 \pm 1.81^{\#}$ & $25.79 \pm 1.85^{\#}$ & $20.74 \pm 1.65^{\dagger}$ \\
\hline $\mathrm{Hb}(\mathrm{g} / \mathrm{dl})$ & $14.19 \pm 1.08$ & $14.12 \pm 0.73$ & $7.26 \pm 0.40^{*}$ & $10.12 \pm 0.65^{\#}$ & $10.81 \pm 0.52^{\#}$ & $12.73 \pm 0.94^{\dagger}$ \\
\hline $\mathrm{HbA}_{1 \mathrm{C}}(\mathrm{mg} / \mathrm{g}$ of $\mathrm{Hb})$ & $0.45 \pm 0.03$ & $0.40 \pm 0.03$ & $1.82 \pm 0.09^{*}$ & $0.74 \pm 0.06^{\#}$ & $0.65 \pm 0.05^{\#}$ & $0.52 \pm 0.03^{\dagger}$ \\
\hline
\end{tabular}

Values are means \pm S.D. (six readings from ten mice). Duncan's multiple range test (DMRT) was used. ${ }^{\star} p \leq 0.05$ compared with control mice; ${ }^{\#, \dagger} p \leq 0.05$ compared with HFD mice. UA, ursolic acid; RSG, rosiglitazone; HFD, high fat diet; Hb, hemoglobin; HbA $1 \mathrm{C}$, glycosylated hemoglobin.

Table 2. Effect of UA and RSG on the activities of hepatic carbohydrate metabolic enzyme and glycogen content in HFD-fed C57BL/6J mice

\begin{tabular}{|c|c|c|c|c|c|c|}
\hline & Control & $\mathrm{UA}+\mathrm{RSG}$ & HFD & $\mathrm{HFD}+\mathrm{UA}$ & HFD+RSG & $\mathrm{HFD}+\mathrm{UA}+\mathrm{RSG}$ \\
\hline $\begin{array}{l}\text { Liver glycogen } \\
\text { (mg/100g tissue) }\end{array}$ & $49.19 \pm 3.56$ & $53.28 \pm 0.96$ & $21.35 \pm 5.27^{\star}$ & $40.48 \pm 3.85^{\#}$ & $38.67 \pm 2.99^{\#}$ & $45.15 \pm 3.67^{\dagger}$ \\
\hline $\begin{array}{l}\text { Glucokinase } \\
\text { (mmol of glucose phosphorylated } \\
\text { per h /mg protein) }\end{array}$ & $0.29 \pm 0.011$ & $0.28 \pm 0.014$ & $0.12 \pm 0.04^{*}$ & $0.17 \pm 0.015^{\#}$ & $0.20 \pm 0.014^{\#}$ & $0.25 \pm 0.018^{\dagger}$ \\
\hline $\begin{array}{l}\text { Glucose 6-phosphatase } \\
\text { (mmol of Pi liberated per } \mathrm{min} / \mathrm{mg} \\
\text { protein) }\end{array}$ & $0.19 \pm 0.013$ & $0.18 \pm 0.017$ & $0.46 \pm 0.032^{\star}$ & $0.35 \pm 0.022^{\#}$ & $0.32 \pm 0.025^{\#}$ & $0.22 \pm 0.019^{\dagger}$ \\
\hline $\begin{array}{l}\text { Fructose } 1,6 \text {-bis phosphatase } \\
\text { (mmol of Pi liberated per } \mathrm{h} / \mathrm{mg} \\
\text { protein) }\end{array}$ & $0.38 \pm 0.020$ & $0.37 \pm 0.025$ & $0.74 \pm 0.046^{\star}$ & $0.49 \pm 0.043^{\#}$ & $0.48 \pm 0.042^{\#}$ & $0.40 \pm 0.025^{\dagger}$ \\
\hline
\end{tabular}

Values are means \pm S.D. (six readings from ten mice). Duncan's multiple range test (DMRT). ${ }^{\star} p \leq 0.05$ compared with control mice; $\#, \dagger p \leq 0.05$ compared with HFD mice. For abbreviations, see Table 1. 


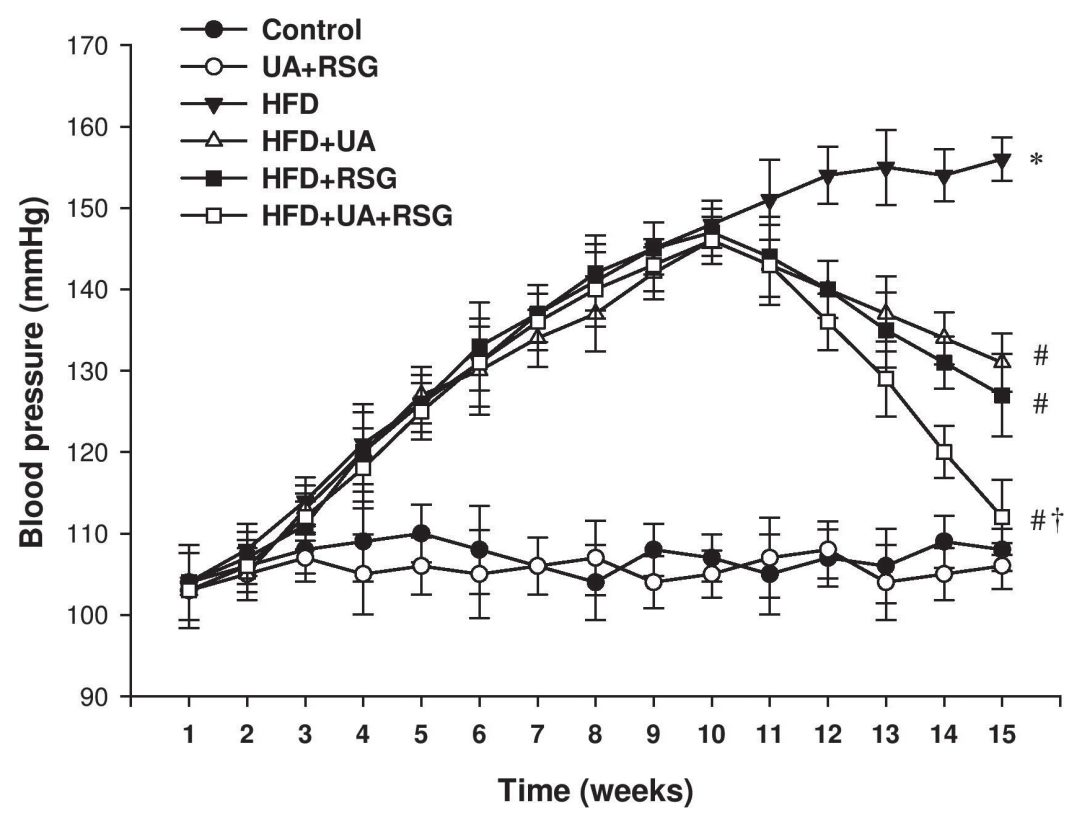

Figure 3. Effect of UA and RSG on systolic blood pressure level in HFD-fed C57BL/6J mice. Values are means \pm S.D. (six readings from ten mice). Duncan's multiple range test (DMRT) was used. ${ }^{\star} p \leq 0.05$ compared with control mice; ${ }^{\sharp \dagger} p \leq 0.05$ compared with HFD mice.

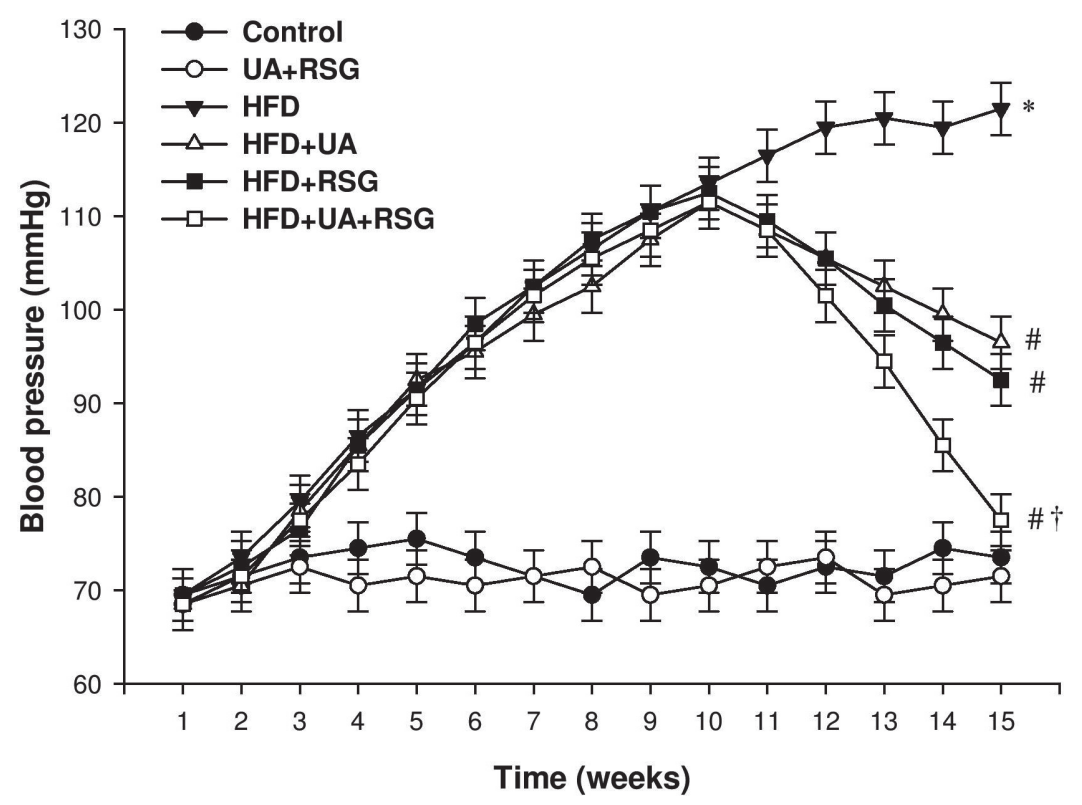

Figure 4. Effect of UA and RSG on diastolic blood pressure level in HFD-fed C57BL/6J mice. Values are means \pm S.D. (six readings from ten mice). Duncan's multiple range test (DMRT). ${ }^{*} p \leq 0.05$ compared with control mice; ${ }^{\#, \dagger} p \leq 0.05$ compared with HFD mice.

Plasma glucose, insulin blood $\mathrm{Hb}$ and $\mathrm{HbA1c}$ level

Table 1 illustrates the plasma glucose, insulin, blood $\mathrm{Hb}$ and HbA1c levels in HFD mice. The levels of plasma glucose, insulin and $\mathrm{HbAlc}$ increased significantly and $\mathrm{Hb}$ level decreased in the HFD group. UA or RSG alone treatment showed a significant reduction in plasma glucose, insulin and $\mathrm{HbA1c}$ while hemoglobin increased whereas combination treatment (UA/RSG) had significant lowering effect than individual compound. 
A

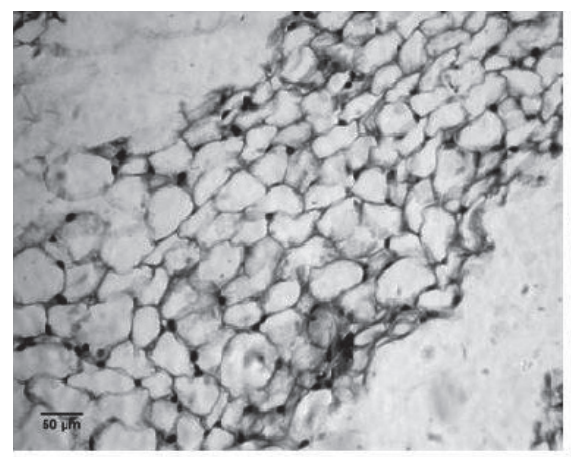

Control

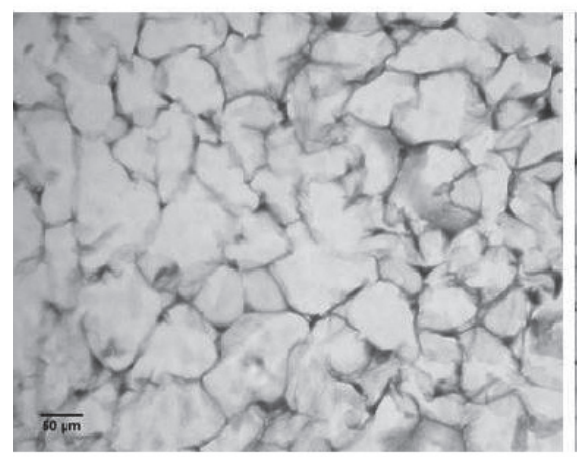

HFD + UA

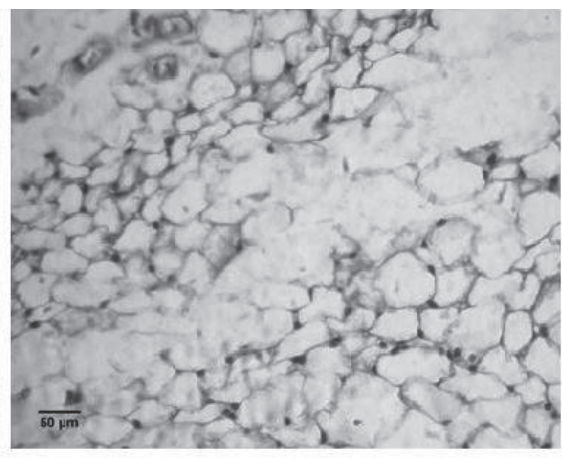

UA + RSG

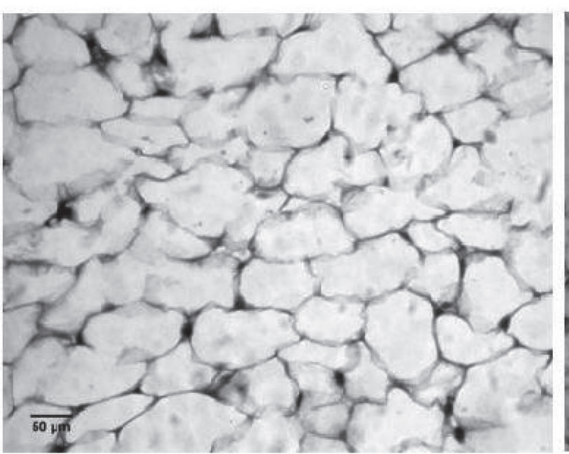

HFD + RSG

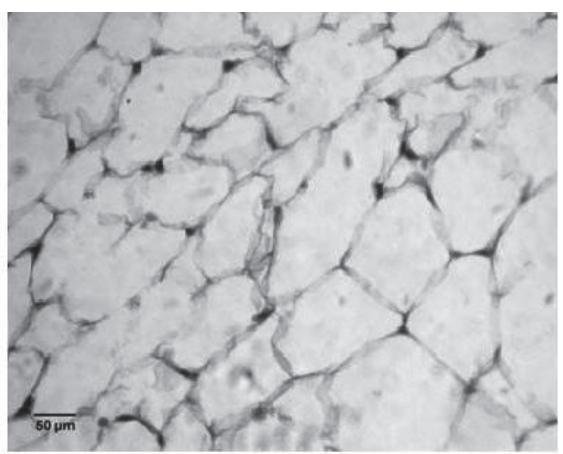

HFD

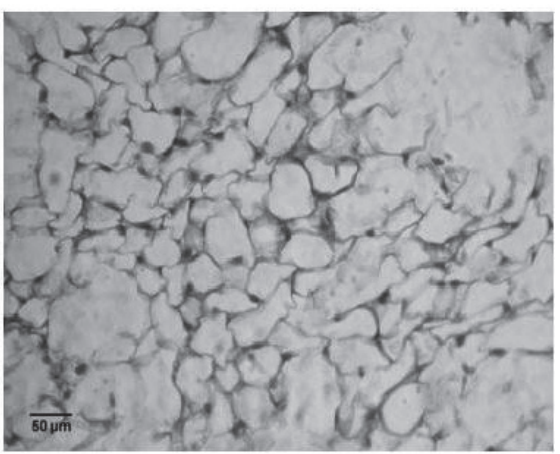

HFD + UA + RSG

B

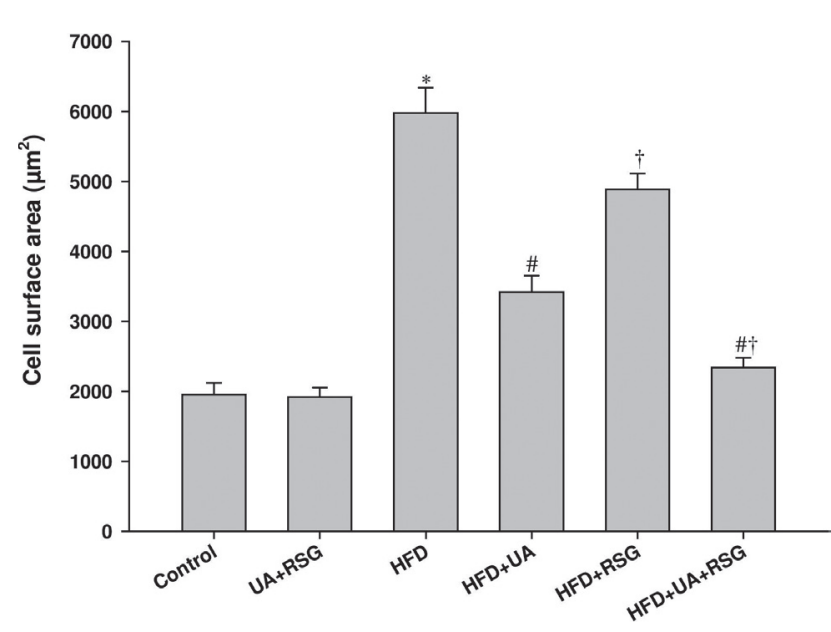

Hepatic glucose regulating enzyme activities and glycogen level

The activities of carbohydrate metabolic enzymes and level of glycogen in the liver of HFD mice are given in Table 2. The hepatic glucokinase activity lowered significantly, and the activi-
Figure 5. A. Effect of UA and RSG on adipose tissues histopathological variations in HFD-fed C57BL/6J mice. Hematoxylin and eosin staining of the adipose tissues. Micrographs were taken at magnification $\times 20$. B. Measurement of mean adipocyte area by using Image J software. Histogram depicts measurement of Mean adipocyte area using by Image J software. 3 images were taken from three mice tissues in a group. Bars represent mean \pm S.D, $n=3$ mice. At least 300-400 cells per 1 animal were evaluated. Values not sharing a common marking $\left({ }^{*}, \#, \dagger, \# \dagger\right)$ differ significantly at $p \leq 0.05$ (DMRT).

ties of fructose-1,6-bisphosphatase and glucose-6-phosphatase increased significantly in the HFD group. Treatment with UA and RSG brought the above changes towards normality and combination treatment (UA/RSG) further significantly influenced towards normality. Glycogen content also improved more significantly in combination treatment than lone treatment. 


\section{Plasma lipid profile}

Table 3 shows the level of plasma TC, TG, HDL-C, VLDL-C, LDL-C, FFA and phospholipids in HFD mice. The HFD mice had elevated levels of plasma TC, TG, LDL-C, VLDL-C, FFA and phospholipids and decreased level of HDL-C. Supplementation of UA and RSG alone brought these levels towards normality, while combination treatment (UA/RSG) further influenced significantly towards normality.

\section{Blood Pressure}

Figures 3 and 4 show the systolic and diastolic blood pressure of HFD mice, respectively. The systolic and diastolic blood pressure was significantly higher in the HFD fed group than in the control group. Treatment with UA and RSG alone significantly reduced the systolic and diastolic blood pressure levels towards normality, while combination treatment (UA/ RSG) further influenced significantly towards normality.

\section{Histopathology of adipose tissue}

Figure 5A shows the effect of UA and RSG on adipose tissues histopathological variations in HFD-fed. HFD mice show an expansion of adipocytes with increased fat accumulation. HFD mice + UA restore the normal size of the adipocytes. HFD mice + RSG show minimal expansion of adipocytes with fat distribution. HFD mice + UA/RSG significantly restore the normal size of the adipocytes. All scale bars equal to $50 \mu \mathrm{m}$.

\section{Discussion}

The metabolic syndrome, such as insulin resistance and lipid disorder, can be induced by a HFD feeding in C57BL/6J mice (Cong et al. 2008). The duration of a HFD feeding and the lipid contents and type of the diets lead to alterations in the degree of insulin resistance and in the lipid metabolic parameters (Choi et al. 2007). The results of the present study revealed that feeding HFD to C57BL/6J mice for ten weeks could develop metabolic abnormalities including overweight, hyperglycemia, dyslipidemia, hyperinsulinemia, insulin resistance and hypertension. UA/RSG combination improved the above changes towards normality, which was more pronounced than UA or RSG alone.

HFD has been shown to produce more rapid weight gain in rodents (Cong et al. 2008) especially C57BL/6J mice (Surwit et al. 1998). In the present experiment, over a period of 10 weeks, HFD-fed mice showed statistically significant drastic weight gain than control group. Consumption of the HFD led to obesity as it facilitates the development of a positive energy balance leading to an increase in visceral fat deposition; this led to abdominal obesity in particular. Moreover, HFD feeding is accompanied by molecular adaptations that errand fat storage in muscle rather than oxidation (Schrauwen-Hinderling et al. 2005). Treatment with UA alone or combination with RSG reduced the body weight gain, and the effect was particularly marked in epididymal adipose tissues. RSG alone treated animals had minimal body weight loss when compared with HFD mice. RSG, a member of the TZD class of antidiabetic agents, is selective synthetic ligand of PPAR- $\gamma$. One of the side effects of PPAR- $\gamma$ ligand is their tendency to increase body weight gain, which is a risk factor for type 2 diabetes. PPAR- $\gamma$ increases adipogenesis by stimulating adipocyte differentiation (Lowell 1999) which may explain the effect of RSG on body weight gain. The minimal reduction of body weight gain observed in RSG treatment mice may be due to the influence of RSG on both carbohydrate and lipid metabolism.

HFD-fed group showed significant increase in the plasma glucose, insulin, decreased blood $\mathrm{Hb}$ and increased $\mathrm{HbAlc}$ level, indicating development of insulin resistance. Several

Table 3. Effect of UA and RSG on plasma TC, TG, HDL-C, LDL-C, VLDL-C, FFA and PL levels in HFD-fed C57BL/6J mice

\begin{tabular}{lcccccc}
\hline Substance $(\mathrm{mg} / \mathrm{dl})$ & Control & UA+RSG & HFD & HFD+UA & HFD+RSG & HFD+UA+RSG \\
\hline TC & $75.54 \pm 7.39$ & $73.49 \pm 7.22$ & $179.73 \pm 17.94^{*}$ & $126.75 \pm 11.54^{\#}$ & $115.86 \pm 10.43^{\#}$ & $89.21 \pm 8.94^{\dagger}$ \\
TG & $61.24 \pm 5.76$ & $59.45 \pm 4.13$ & $158.42 \pm 14.92^{*}$ & $91.43 \pm 7.38^{\#}$ & $84.42 \pm 6.46^{\#}$ & $67.27 \pm 5.29^{\dagger}$ \\
HDL-C & $47.90 \pm 3.28$ & $49.51 \pm 4.21$ & $26.48 \pm 2.45^{*}$ & $34.21 \pm 3.25^{\#}$ & $35.15 \pm 3.55^{\#}$ & $43.09 \pm 3.34^{\dagger}$ \\
LDL-C & $15.39 \pm 1.41$ & $12.08 \pm 1.17$ & $121.57 \pm 10.29^{*}$ & $74.25 \pm 6.46^{\#}$ & $63.82 \pm 5.88^{\#}$ & $32.67 \pm 2.13^{\dagger}$ \\
VLDL-C & $12.25 \pm 1.41$ & $11.90 \pm 1.17$ & $31.68 \pm 2.44^{*}$ & $18.29 \pm 1.62^{\#}$ & $16.89 \pm 1.41^{\#}$ & $13.45 \pm 1.54^{\dagger}$ \\
FFA & $54.46 \pm 5.28$ & $52.48 \pm 5.30$ & $143.75 \pm 14.25^{*}$ & $112.37 \pm 10.54^{\#}$ & $104.63 \pm 10.30^{\#}$ & $72.84 \pm 5.97^{\dagger}$ \\
PL & $78.45 \pm 5.52$ & $75.49 \pm 5.76$ & $174.25 \pm 15.90^{*}$ & $110.23 \pm 9.52^{\#}$ & $118.54 \pm 10.77^{\#}$ & $87.09 \pm 6.51^{\dagger}$ \\
\hline
\end{tabular}

Values are means \pm S.D. (six readings from ten mice). Duncan's multiple range test (DMRT). ${ }^{\star} p \leq 0.05$ compared with control mice; ${ }^{\#, \dagger} p \leq 0.05$ compared with HFD mice. TC, total cholesterol; TG, triglyceride; HDL-C, high-density lipoprotein cholesterol; LDL-C, lowdensity lipoprotein cholesterol; VLDL-C, very low-density lipoprotein cholesterol; FFA, free fatty acids; PL, phospholipids. 
studies documented that insulin resistance most often precedes the onset of overt type 2 diabetes mellitus and is compensated initially by hyperinsulinemia (Evans et al. 2003). This hyperinsulinemia is produced by both compensatory insulin hypersecretion and by reduced hepatic extraction of insulin (Polonsky et al. 1988). In general, hyperglycemia is characterized by a reduction in insulin-mediated glucose disposal in type 2 diabetes mellitus (Ginsberg et al. 1975). In the present study UA/RSG combined treatment significantly reduced the plasma glucose and insulin level and the improvement in glycemic control is attributed to mechanisms that involve insulin action rather than insulin secretion. Insulin generally has an anabolic effect on protein metabolism in that it stimulates protein synthesis and retards protein degradation and thus, decreasing the synthesis of $\mathrm{Hb}$. $\mathrm{HbAlc}$ is an indicator of blood glucose level for the previous 2-3 months. The HbAlc level is used as both an index of glycemia and as risk factors for the development of diabetic complications (Tahara and Shima 1995). The combination treatment (UA/RSG) significantly increased blood Hb level and lowered the HbAlc level. These results suggest that combination treatment (UA/RSG) can contribute to the management of the disease.

Previous reports revealed that the hypoglycemic effect of UA (Jayaprakasam et al. 2006) and RSG (Balfour and Plosker 1999) seems to be mediated by changes in the hepatic glucose regulating enzyme activities in the experimental animals. In general, increased hepatic glucose production, plus decreased hepatic glycogen synthesis and glycolysis, are the major changes in type 2 diabetes that result in hyperglycemia. These would seem to be the consequence of the low glucokinase activity and high glucose-6-phosphatase and fructose-1,6bisphosphatase activity in a diabetic state (Guignot and Mithieux 1999). Hepatic glucokinase has a major effect on glucose homeostasis and is a potential target for the pharmacological treatment of type 2 diabetes. An increase of hepatic glucokinase activity can cause increased utilization of blood glucose for energy production or glycogen storage in the liver (Postic et al. 1999). Glucose-6-phosphatase catalyzes the last enzymatic reaction, which is also included in gluconeogenesis reactions, and confers on the liver the capacity to release glucose in the blood. Due to their strategic positions in the liver glucose metabolism, both these enzymes are supposed to be the target of important regulatory mechanisms of hepatic glucose production (Foster et al. 1997). Glycogen synthesis and insulin sensitivity are closely related. Decreased insulinstimulated glycogen synthesis and glucose transport activity are observed in insulin resistance (Petersen and Shulman 2006). In this study, UA/RSG seemed to mediate glycogen metabolism by stimulating glucokinase activity and inhibiting glucose-6-phosphatase and fructose-1,6-bisphosphatase activities in the liver of C57BL/6 mice, which is as indicated by the higher amounts of hepatic glycogen in the liver.
Both FFA and TG content are significantly high in the plasma of HFD fed mice. High plasma FFA level is known to contribute to insulin resistance by inhibiting insulin signaling and also by suppressing pancreatic insulin secretion (Arner 2003). Elevation in plasma FFA level in obesity and type 2 diabetes mellitus has been accredited to non-esterification in the adipose tissue and the consequent escape from the adipose tissue to the plasma (Riemens et al. 2000). The high plasma TG level can be related with increased hepatic synthesis using the freely available FFA and the resultant hypertriglycerdemia in turn can contribute to insulin resistance (Grundy 1999). In the present study UA/RSG combined treatment significantly reduced the plasma FFA and TG levels.

The level of TC in plasma is the major determinant of the risk of cardiovascular disease. Lowering the level of LDL-C diminishes the risk in those with and without symptomatic vascular disease. Hypercholesterolemia may be attributed to increased dietary cholesterol absorption from the small intestine following the intake of HFD in a diabetic condition (Proietto 2005) and/or alteration of cholesterol metabolism in insulin resistance state. This alteration could result from increased glycation of LDL-C, thus decreasing its catabolism, and from decreased hepatic LDL-C receptor activity (Taskinen et al. 1986). Moreover, glycosylated apo-protein B in LDL-C blocks receptor-mediated LDL-C catabolism in vivo, which reduces LDL-C clearance in hyperglycemic patients (Steinbrecher and Witztum 1984). In addition, the reverse cholesterol transport pathway is also altered in diabetes through a diminution in HDL-C concentrations (Monnier et al. 1995). Our data clearly showed that feeding of HFD for 10 weeks increased the concentration of plasma TC, LDL-C and decreased the level of HDL-C. UA/RSG combined treatment produced significant decrease in serum TG and LDL-C while there was a significant increase in HDL-C. These results are in accordance with the known hypolipidaemic effects of UA (Jayaprakasam et al. 2006) and TZDs (Ding et al. 2005) in mice. Insulin resistance is associated not only with hyperinsulinemia and hyperglycemia but also with other disorders such as abnormal lipid profile disturbances, which was improved after treatment with UA and RSG.

Hypertension is one of the diagnostic criteria for the metabolic syndrome. A close relationship between insulin resistance and hypertension has also been well established (Semenkovich 2006). Fasting insulin levels are directly correlated with blood pressure levels. Furthermore, insulin resistance and hyperinsulinemia are found in animal models of hypertension (Sowers 2004). The present study revealed that HFD-fed mice showed marked elevation in blood pressure. Combination treatment with UA/RSG mice significantly reduced the blood pressure when compared to HFD-fed mice. These results are in accordance with the known antihypertensive effects of UA (Somova et al. 2003) and RSG (Wu et al. 2004). 
In conclusion, UA with RSG is a potential candidate for the prevention and treatment of Metabolic Syndrome associated with insulin resistance, type 2 diabetes mellitus, obesity, dyslipidemia and hypertension. Addition of UA with RSG may reduce the number of adverse side effects associated with the RSG based therapy.

Acknowledgement. The financial support to Arjunan Sundaresan as Senior Research Fellowship from Indian Council of Medical Research, New Delhi, is gratefully acknowledged.

\section{References}

Arner P. (2003): The adipocyte in insulin resistance: key molecules and the impact of the thiazolidinediones. Trends Endocrinol. Metab. 14, 137-145 http://dx.doi.org/10.1016/S1043-2760(03)00024-9

Balanehru S., Nagarajan B. (1991): Protective effect of oleanolic acid and ursolic acid against lipid peroxidation. Biochem. Int. 24, 981-990.

Balfour J. A., Plosker G. L. (1999): Rosiglitazone. Drugs 57, 921-932 http://dx.doi.org/10.2165/00003495-199957060-00007

Bancroft J. D., Gamble M. (2002): Theory and practice of histological techniaques. (5th edition, China), Churchill Livingstone

Brandstrup N., Kirk J. E., Brunic C. (1957): Determination of glucokinase in tissues. J. Gerontol. 12, 166-171

Burgi W., Briner M., Franken N., Kessler A. C. (1998): One step sandwich enzyme immunoassay for insulin using monoclonal antibodies. Clin. Biochem. 21, 311-314 http://dx.doi.org/10.1016/S0009-9120(88)80087-0

Choi J. S., Koh I. U., Jung M. H., Song J. (2007): Effects of three different conjugated linoleic acid preparations on insulin signalling, fat oxidation and mitochondrial function in rats fed a high-fat diet. Br. J. Nutr. 98, 264-275 http://dx.doi.org/10.1017/S000711450770497X

Cong W. N., Tao R. Y., Tian J. Y., Liu G. T., Ye F. (2008): The establishment of a novel nonalcoholic steatohepatitis model accompanied with obesity and insulin resistance in mice. Life Sciences 82, 983-990 http://dx.doi.org/10.1016/j.lfs.2008.01.022

DeFronzo R. A. (2004): Pathogenesis of type 2 diabetes mellitus. Med. Clin. North. Am. 88, 787-835 http://dx.doi.org/10.1016/j.mcna.2004.04.013

Diamant M., Hein R. J. (2003): Thiazolidinediones in type 2 diabetes mellitus: Current clinical evidence. Drugs 63, 1373-1405 http://dx.doi.org/10.2165/00003495-200363130-00004

Ding S. Y., Shen Z. F., Chen Y. T., Sun S. J., Liu Q., Xie M. Z. (2005): Pioglitazone can ameliorate insulin resistance in low-dose streptozotocin and high sucrose-fat diet induced obese rats. Acta Pharmacologica. Sinica. 26, 575-580 http://dx.doi.org/10.1111/j.1745-7254.2005.00090.x

Drabkin D. L., Austin J. M. (1932): Spectrophotometric constants for common haemoglobin derivatives in human, dog and rabbit blood. J. Biol. Chem. 98, 719-733
Evans J. L., Goldfine I. D., Maddux B. A., Grodsky G. M. (2003): Are oxidative stress-activated signaling pathways mediators of insulin resistance and $\beta$-cell dysfunction? Diabetes 52, 1-8 http://dx.doi.org/10.2337/diabetes.52.1.1

Falholt K., Lund B., Falholt W. (1973): An easy colorimetric method for routine determination of free fatty acids in the plasma. Clin. Chim. Acta 46, 105-111 http://dx.doi.org/10.1016/0009-8981(73)90016-8

Feldstein A. E., Canbay A., Guicciardi M. E., Higuchi H., Bronk S. F., Gores G. J. (2003): Diet associated hepatic steatosis sensitizes to Fas mediated liver injury in mice. J. Hepatol. 39, 978-983 http://dx.doi.org/10.1016/S0168-8278(03)00460-4

Fiske C. H., Subbarow Y. (1925): The colorimetric determination of phosphorus. J. Biol. Chem. 66, 375-392

Foster J. D., Pederson B. A., Nordlie R. C. (1997): Glucose-6-phosphatase structure, regulation, and function: an update. Proc. Soc. Exp. Biol. Med. 215, 314-332

Friedewald W. T., Levy R. I., Fredrickson D. S. (1972): Estimation of LDL-cholesterol in the plasma, without the use of preparative ultracentrifuge. Clin. Chem. 18, 449

Gancedo J. M., Gancedo C. (1971): Fructose 1, 6-bisphophatase, phosphofructokinase and glucose 6-phosphate dehydrogenase from fermenting yeast and non-fermenting yeast. Arch. Microbiol. 76, 132-138 http://dx.doi.org/10.1007/BF00411787

Ginsberg H., Kimmerling G., Olefsky J. M., Reaven G. M. (1975): Demonstration of insulin resistance in untreated adult onset diabetic subjects with fasting hyperglycemia. J. Clin. Invest. $55,454-461$ http://dx.doi.org/10.1172/JCI107951

Grundy M. (1999): Hypertriglyceridemia, insulin resistance, and metabolic syndrome. Am. J. Cardiol. 83, 25F-29 http://dx.doi.org/10.1016/S0002-9149(99)00211-8

Guignot L., Mithieux G. (1999): Mechanisms by which insulin, associated or not with glucose, may inhibit hepatic glucose production in the rat. Am. J. Physiol. 277, 984-989

Jayaprakasam B., Olson L. K., Schutzki R. E., Tai M. H., Nair G. M. (2006): Amelioration of obesity and glucose intolerance in high-fat-fed C57BL/6 mice by anthocyanins and ursolic acid in Cornelian cherry (Cornus mas). J. Agric. Food Chem. 54, 243-248 http://dx.doi.org/10.1021/jf0520342

Koide H., Oda T. (1959): Pathological occurrence of glucose 6-phosphatase in serum in liver diseases. Clin. Chim. Acta 4, 554 http://dx.doi.org/10.1016/0009-8981(59)90165-2

Kolovou G. D., Anagnostopoulou K. K., Cokkinos D. V. (2005): Pathophysiology of dyslipidaemia in the metabolic syndrome. Postgrad. Med. J. 81, 358-366 http://dx.doi.org/10.1136/pgmj.2004.025601

Lim S., Yoonk J. W., Choi S. H., Cho B. J., Kim J. T., Chang H. S., Park H. S., Park K. S., Lee H. K., Kim Y. B., Jang H. C. (2009): Effect of ginsam, a vinegar extract from Panax ginseng, on body weight and glucose homeostasis in an obese insulin-resistant rat model. Metabolism 58, 8-15 http://dx.doi.org/10.1016/j.metabol.2008.07.027

Liu J. (1995): Pharmacology of oleanolic acid and ursolic acid. J. Ethnopharmacol. 49, 57-68 http://dx.doi.org/10.1016/0378-8741(95)90032-2 
Lowell B. B. (1999): PPAR: an essential regulator of adipogenesis and modulator of fat cell function. Cell 99, 239-242 http://dx.doi.org/10.1016/S0092-8674(00)81654-2

Masoudi F. A., Wang Y., Inzucchi S. E., Setaro J.F., Havranek E. P., Foody J. M., Krumholz H.M. (2003): Metformin and thiazolidinedione use in medicare patients with heart failure. JAMA. 290, 81-88 http://dx.doi.org/10.1001/jama.290.1.81

Monnier L., Colette C., Percheron C., Descomps B. (1995): Insulin, diabetes and cholesterol metabolism. C. R. Seances Soc. Biol. Fil. 189, 919-931

Morales M. A., Jabbagy A. J., Terenzi H. P. (1975): Mutations affecting accumulation of glycogen. Neurospora. News Lett. 20, 24-25

Petersen K. F., Shulman G. I. (2006): Etiology of insulin resistance. Am. J. Med. 119, S10-16 http://dx.doi.org/10.1016/j.amjmed.2006.01.009

Polonsky K. S., Given B. D., Hirsch L., Shapiro E. T., Tillil H., Beebe C., Galloway J. A., Frank B. H., Karrison T., Van Cauter E. (1988): Quantitative study of insulin secretion and clearance in normal and obese subjects. J. Clin. Invest. 81, 435-441 http://dx.doi.org/10.1172/JCI113338

Postic C., Shiota M., Niswender K. D., Jetton T. L., Chen Y., Moates J. M., Shelton K. D., Lindner J., Cherrington A. D., Magnuson M. A. (1999): Dual roles for glucokinase in glucose homeostasis as determined by liver and pancreatic beta cell-specific gene knockouts using Cre recombinase. J. Biol. Chem. 274, 305-315 http://dx.doi.org/10.1074/jbc.274.1.305

Proietto J. (2005): Mechanisms of insulin resistance caused by nutrient toxicity. Hepatol. Res. 33, 87-91 http://dx.doi.org/10.1016/j.hepres.2005.09.010

Riemens S. C., Sluiter W. J., Dullaart R. P. (2000): Enhanced escape of non-esterified fatty acids from tissue uptake: its role in impaired insulin-induced lowering of total rate of appearance in obesity and type 2 diabetes mellitus. Diabetologia 43, 416-426 http://dx.doi.org/10.1007/s001250051324

Saravanan R., Pugalendi K. V. (2006): Impact of ursolic acid on chronic ethanol-induced oxidative stress in the rat heart. Pharmacol. Rep. 58, 41-47

Sasaki T., Matsy S., Sonac A. (1972): Effect of acetic and concentration on the colour reaction in the O-toluidine boric acid method for blood glucose estimation. Rinsho Kagaku 1, 346-353

Scheen A. J. (2005): Drug interactions of clinical importance with antihyperglycaemic agents: an update. Drug Saf. 28, 601-631 http://dx.doi.org/10.2165/00002018-200528070-00004

Schrauwen-Hinderling V. B., Kooi M. E., Hesselink M. K., MoonenKornips E., Schaart G., Mustard K. J., Hardie D. G., Saris W. H., Nicolay K. (2005): Intramyocellular lipid content molecular adaptations in response to a 1-week high-fat diet. Obes. Res. 13, 2088-2094 http://dx.doi.org/10.1038/oby.2005.259

Semenkovich C. F. (2006): Insulin resistance and atherosclerosis. J. Clin. Invest. 116, 1813-1822 http://dx.doi.org/10.1172/JCI29024

Senthil S., Chandramohan G., Pugalendi K. V. (2007): Isomers (oleanolic acid ursolic acids) differ in their protective effect against isoproterenol-induced myocardial schemic in rats. Int. J. Cardiol. 119, 131-133 http://dx.doi.org/10.1016/j.ijcard.2006.07.108

Sohn K. H., Lee H. Y., Chung H. Y., Young H. S., Yi S. Y., Kim K. W. (1995): Anti-angiogenic activity of triterpene acids. Cancer Lett. 94, 213-218 http://dx.doi.org/10.1016/0304-3835(95)03856-R

Somova L. O., Nadar A., Rammanan P., Shode F. O. (2003): Cardiovascular, antihyperlipidemic and antioxidant effects of oleanolic and ursolic acids in experimental hypertension. Phytomedicine 10, $115-121$

http://dx.doi.org/10.1078/094471103321659807

Sowers J. R. (2004): Insulin resistance and hypertension. Am. J. Physiol. Heart. Circ. Physiol. 286, H1597-1602 http://dx.doi.org/10.1152/ajpheart.00026.2004

Steinbrecher U. P., Witztum J. L. (1984): Glucosylation of low-density lipoproteins to an extent comparable to that seen in diabetes slows their catabolism. Diabetes 33, 130-134 http://dx.doi.org/10.2337/diabetes.33.2.130

Sudhakar N. S., Pattabiraman T. N. (1981): A new colorimetric method for the estimation of glycosylated haemoglobin. Clin. Chim. Acta 109, 267-274 http://dx.doi.org/10.1016/0009-8981(81)90312-0

Surwit R. S., Kuhn C. M., Cochrane C., McCubbin J. A., Feinglos M. N. (1998): Diet-induced type II diabetes in C57BL/6J mice. Diabetes 37, 1163-1167 http://dx.doi.org/10.2337/diabetes.37.9.1163

TaharaY., Shima K. (1995): Kinetics of HbA1c, glycated albumin, and fructosamine and analysis of their weight functions against preceding plasma glucose level. Diabetes Care. 18, 440-447 http://dx.doi.org/10.2337/diacare.18.4.440

Taskinen M. R., Beltz W. F., Harper I., Fields R. M., Schonfeld G., Grundy S. M., Howard B. V. (1986): Effects of NIDDM on very-low-density lipoprotein triglyceride and apo-lipoprotein B metabolism. Studies before and after sulfonylurea therapy. Diabetes 35, 1268-1277 http://dx.doi.org/10.2337/diabetes.35.11.1268

Vidal-Puig A. J., Considine R. V., Jimenez-Liñan M., Werman A, Pories W. J., Caro J. F., Flier J. S. (1977): Peroxisome proliferator-activated receptor gene expression in human tissues Effects of obesity, weight loss, and regulation by insulin and glucocorticoids. J. Clin. Invest. 99, 2416-2422

http://dx.doi.org/10.1172/JCI119424

Wu L., Wang R., De Champlain J., Wilson T. W. (2004): Beneficial and deleterious effects of rosiglitazone on hypertension development in spontaneously hypertensive rats. Am. J. Hypertens. 17, 749-756 http://dx.doi.org/10.1016/j.amjhyper.2004.04.010

Yip J., Facchini F. S., Reaven G. M. (1998): Resistance to insulinmediated glucose disposal as a predictor of cardiovascular disease. J. Clin. Endocrinol. Metab. 83, 2773-2776 http://dx.doi.org/10.1210/jc.83.8.2773

Zhang W., Hong D., Zhou Y., Zhang Y., Shen Q., Li J. Y., Hu L. H., Li J. (2006): Ursolic acid and its derivative inhibit protein tyrosine phosphatase $1 \mathrm{~B}$, enhancing insulin receptor phosphorylation and stimulating glucose uptake. Biochim. Biophys. Acta 1760, $1505-1512$

http://dx.doi.org/10.1016/j.bbagen.2006.05.009

Received: December 9, 2011

Final version accepted: May 3, 2012 